\title{
Study of Strengthening Student Union Cadres under New Era Xiangdong $\mathrm{Ma}^{1}$ \\ ${ }^{1}$ College of literature Arts of Yulin University, Yulin, Shaanxi, 719000 \\ hunter2011@foxmail.com
}

Keywords: Student Union; Monitoring Mechanisms; Construction of Colleges; New Era

\begin{abstract}
How to strengthen the construction of college student cadres? Firstly, to fully mobilize the enthusiasm of student cadres work under a people-centered concept, and play student cadres the "concern, enthusiasm, patience," the role in strengthening student cadres quality construction and management; Secondly, to promote the proper management concepts, constantly enhance service awareness, innovative spirit and sense of responsibility; Furthermore, improve students' self-monitoring mechanism to ensure the student is working properly and orderly and healthy development. But also exercise the individual's ability to meet the needs of social development.
\end{abstract}

\section{Introduction}

The status of student union in the universities reflects the students in universities and roles in place, reflecting the emphasis of College Students' work [1]. Student Union organized grassroots self-organization college students, the majority of students in a people-centered concept of service our students 'organization, reflecting students' interest, enthusiasm, patience, "the sense of responsibility, to become the vanguard of self-education, management and services, and in College Cultural Building and plays an irreplaceable role. Students' Union has been committed to building a good style of study, build campus culture with regional characteristics, in order to actively construct harmonious campus culture of sustainable development efforts. In recent years, with the deepening social and economic development and higher education reform and changing patterns of personnel training, college students of the world, life and values are constantly changing, more and more students in addition to learning In addition, more focus on training their actual ability. This change to the development of student cadres Quality construction and management has role in promoting student cadres motivated, enthusiastic, high morale, continue to strengthen the sense of service and innovation, and establish a strong sense of responsibility. Self-monitoring, self-improvement, self-development, and play a good role as a link student cadre at work. Continue to exercise their own to meet the immediate needs of social development, to adapt to the new situation, and create a new situation.

\section{Student Cadres Team Building Needs to Make "Three Strengthen" Work}

Student Union Student Union is the core of leadership, strengthen the student union building is the need to protect the development of the Student Union, students are a big group, you want to make a cohesive, it is imperative to strengthen the three well, namely strengthening the student cadre management, strengthen student cadres the building and strengthening the management of student work.

Strengthening Management of Student Leaders. The fundamental problem lies in the management of human understanding [2]. The quality of student work depends on a sense of the quality of student cadres overall co-ordination and leadership ability, but built on a full understanding of the student leaders on the basis of student leaders is crucial appointment, which will be related to students overall development trend.

1, Student selection and appointment of cadres. Includes the following four aspects: (1) thought motivated, volunteer services for students; (2) overall situation, unity of the students; (3) can be strict with themselves, to comply with school rules; (4) can correctly handle the relationship 
between learning and work, to learning the Lord.

2, Good training and assessment work student leaders. Requirements for student cadres are comprehensive appraisal from all aspects of culture and thought, life and ability to learn. First, develop their unwavering belief in socialism and serve the people wholeheartedly consciousness in the ideological and political aspects. Secondly, in life learning to love learning, love of life, friendship and getting along with classmates, to promote mutual learning, help each other in life. Finally, in the capacity, we should have a strong sense of responsibility, practical careful, pragmatic spirit and a positive attitude. Assessment work is mainly from the self-assessment, students participating in two aspects. First of all, self-assessment is reviewed his own work, advantages and disadvantages. Secondly, in a people-centered concept, in a democratic manner so that the general council of the students participating democracy, in order to comprehensive evaluation of student cadres.

Strengthening the Construction of the Student Union Cadres. Effective and reasonable construction of student cadres to improve the overall quality is the premise of guarantee. For the current status of student cadres, we should study from the following three aspects for construction.

1, Ideological construction. Political theory with practice, the times, forge ahead, to maintain good mental state.

2, Organization building. To strict inspection, selecting the best, recruit more capable, and constantly improve the structure of the construction of the contingent of cadres to rationalization, but is used.

3. Style. Student Leaders must lead by example, impartiality, self-discipline, hard working, carry forward the spirit of seeking truth.

Strengthening the Management of Student Work. Management focus is to create an environment conducive to their full potential in the work environment, managers should not be oversight, directing but to help them overcome obstacles encountered in the process of self-realization [3]. Student work is an opportunity to students to show their strength and ability, so that students will work for a clear division of powers and responsibilities consistent and fully coordinate the relationship between the various departments or other departments. Specifically to:

1, Actively contact department branch and Youth League, coherence between each other. Play bridge and New York, and with good effect.

2, To comply with and implement the Party's policy to carry out related work with faculty on. Such as: organizing lectures quiz to achieve study and implement the party's principles, the party's awareness of students.

3, To "go out" to strengthen ties with other departments of the student organizations in order to better carry out the work. Such as: the annual contest has the support of Chinese characters dictation various faculties, and therefore can be better and better.

\section{Student Cadres Team Building Needs to Take Responsibility to the People, Nuanced Methods of Work}

Students to do real work place, it is necessary responsibility to the people, their duties; work should pay attention to details, the details determine success or failure, a good way to grasp.

Work Should be Put In Place, Responsibility to the People.Student work is for the student services organization, is the communication between students and teachers, the Communist Youth League and other departments and exchange of the bridge must be responsibility to the people, the work carried out, in order to further the good work.

The Work to Be Realistic and Geographical Characteristics.1, In conjunction with the actual situation of their own departments to carry out the work, to take into account more students feel. Such as: Faculty of girls as the majority, to take into account the details of the work in this regard.

2, As a university in northern Shaanxi, northern Shaanxi writers are fond of, and therefore can be more number of activities on literature, reflecting regional characteristics.

The Work Must Play A "Three Hearts" Action and Innovation. Student work must adhere to the people-oriented, the students should be concerned about, for work to be enthusiastic, to deal 
with things to be patient. Do not stick to stereotypes, to dare to discover and solve problems; daring, and constantly improve themselves, the courage to practice and innovation. Such as: students have the functions of different departments similar place, between departments can be combined in order to improve work efficiency; freshman students based on actual learning, self-organized study up on a freshman, played supervise student learning purpose of improving academic performance, so in order to learn the main.

\section{Improve the Quality of Cadres is the Key Point of Student Cadres Team Building,}

The overall quality of students in the new cadre is particularly important from the viewpoint of the environment in which the student union cadres, the status and the burden of responsibility to improve the quality of cadres from the following five aspects.

The Ideological and Political Quality. As a student cadres must adhere to Marxism-Leninism, Mao Zedong Thought, Deng Xiaoping Theory and the "Three Represents", now combined with the actual, applied to the management of student work, adhere to the principle of seeking truth from facts, scientific and rational work.

Title Quality. Learning is the student's first priority, students with learning-based, student cadres should play a leading role, to set an example, to create a good learning atmosphere. But also to win the trust and recognition of students, improve their prestige, there is conducive to work.

Psychological Quality. Student cadres have a good psychological quality, regardless of the exchange with the teacher or have problems and shortcomings in dealing with work, to face deficiencies and shortcomings, the courage to face reality, rational thinking, decisive solution to the problem.

Innovative. Work of the various departments of students each year are similar, all work gradually becomes lifeless, each department students to continue to strengthen their own learning and practice, innovation, the annual work to make their own characteristics. Such as: "that healthy atmosphere • Atmosphere • circle dream" speech contest venue compared to previous years, more people feel warm and comfortable.

Teamwork. Students will carry out the work required a unified plans and arrangements, which requires stronger team collaboration capabilities, to unite as one, so as to better carry out the work of the Organization, and will not appear unclear responsibilities, mutual shirk phenomenon, to carry out the work of adverse factors.

\section{Improve Self-Monitoring Mechanism is the Key Point of the Student Cadres Team Building}

Student Leaders shoulder the responsibility, also holds a certain power, it needs oversight to prevent the indiscriminate use of power and monitor mechanism is in order to put an end to the phenomenon of abuse of student cadres. Supervision also depends mainly on supervision of all students student leaders, a sound mechanism only a supporting role.

Student Leaders own capacity is limited, so the work will inevitably be some mistakes or errors, oversight mechanisms can provide comments and suggestions on this, thus reducing the work of errors, reducing losses due to insufficient capacity of certain aspects of student cadres caused.

New ear proposed new requirements for education to college student cadres' construction, but also develop a vision of student cadres, have a great inspiration for the development direction of students. But also provides a bigger stage for the development of students, more room for development. Supervise students continue to develop their own, build into a thought motivated, try hard to learn, conscientious work, collective fine style.

\section{References}

[1] Long-term Education Reform and Development Plan (2010-2020). Beijing: People's Publishing House, 2010.

[2] S.D. Zhou. Management.Higher Education Press, Second edition 2005

[3] J.H. Lin. Management Science. Fudan University Press, October 2003 